\title{
Comparison of outcome of Modified Millard's Incision and Delaire's Functional Method in Primary Repair of Unilateral Cleft Lip.
}

\author{
M Asfand Yar ${ }^{1}$, Burhan Nawaz ${ }^{2}$, Saqib Shakoor ${ }^{3}$ \\ 1,2,3. House Officer Bahawal Victoria Hospital, Bahawalpur \\ Corresponding Author:shazzzsaqib@gmail.com
}

Abstract:

Objective: To contrast results of two surgical methods for correction of Unilateral Cleft lip. Methodology: Prospective study was conducted from October 2018 to October 2019 after ethical approval from institute ethical board. Data was collected than arranged over Microsoft Excel 2007.Variables then formed or for further statistical results data was entered in SPSS version 15.0. Variables were assessed by using. . Standard Deviation and Mean was calculated and presented for quantitative data like age and weight. Frequency (percentages) were calculated and presented for qualitative data such as gender and outome variables. Post stratification statistical chi square test was used to see effect modification. P value $\leq 0.05$ was considerable. Results: Out of $100 \%$ $(n=66)$ unilateral cleft lip patients, 50\% $(n=33)$ patients each were operated with Modified Millard's incision and Delaire's functional method respectively. Various parameters were analyzed - white roll match, cupid bow, lip length and alar dome demonstrated favorable measurements in Millard's group and the vermilion match, scar appearance, nostril symmetry and alar base was better in Delaire's methods. All the differences in these parameters were not statistically significant, except lip length $(\mathrm{p}=0.023)$. Conclusion: Overall clinical outcomes like vermilion match, white roll, and cupid bow appearance was similarly effective in both techniques. Outcome related to lip length was considerable in incision by Millard's technique. Similarly nasal symmetry was better in Delaire's functional method. This leads to significance of one method over other.

Keywords: Primary Repair, Modified Millard’s, Delaire's Functional Method Unilateral Cleft Lip.

DOI: $10.7176 / \mathrm{JMPB} / 54-04$

Publication date: April $30^{\text {th }} 2019$

\section{Introduction}

In our society people has more focus over facial beauty. Any damage or change in facial beauty leads to stress for individuals, their families and also on their relationships. Any facial defacement leads to severe stress for sufferers. Cleft lip and Cleft Palate both are also considered as facial anomalies which occur by birth or it involves deformities of facial bones ${ }^{(1)}$.Now these birth defects arising as health problems in public. Congenital Problems like Cleft lip and palate do not affect mortality or morbidity in a greater rate but a few cases of Cleft lip and Cleft palate are seen. ${ }^{(2)}$

Incidence of these anomalies varies in different races. In Asians its incidence is 1 out of 500 live births, while in Caucasians its incidence is 1 out of 750 live births. In Africans Americans its incidence is 1 out of 2000 live births ${ }^{(3,4)}$. This shows that incidence of these birth defects is common in Asians and least common in Africans and Americans. ${ }^{(3,4)}$. Gender vise cleft lip or palate mainly occur in the males while isolated cleft palate rate is higher in females.

$45 \%$ Cases of cleft lip and cleft palate together seen in population while of single cleft palate is $35 \%$ and of single cleft lip is $20 \%$. Incidence of one sided cleft lip is 9 times greater than the cleft lip of two sides ${ }^{(3,5)}$. These anomalies are surgically been treated by Surgeons from 2000 years. First cleft lip surgery was performed in China by a Chinese physician ${ }^{(6,7)}$. To gain more effective results, different procedures were used to perform. Different amendments were done by different physician in those procedures to get best quality results of cleft lip repair.

Individuals who took interest in cleft lip repair are Le Mesurier in 1949, Tennison in 1952, Randall in 1959,Pfeifer in 1970 or Millard in $1976^{(6-8)}$. In these days Mirault was the person who introduced a technique for maintiaing the length of lip through induction of flap. But this technique was not able to rebuilt the Cupid's bow. After this, Le Mesurier further explained many techniques to form artificial Cupid's bow with rectangular flap. This Technique is considered as an effective way to correct clefts, cupid bow, philtral dimple as well as nasal tip correction. Length of the lip was highly appreciated through this technique ${ }^{(9,10)}$. After these advancements all attentions were diverted towards the correction of anatomical changes of cleft lip. Through repairing of 
orbicularis oris muscle the shape of the upper lip was improved which got more precision with the passage of age $^{(11)}$.

Delaire explained the functional repair of cleft lip in a good manner. Delaire lifted the functional matrix as he dissected the sub periosteal up to the level of nasal septum. After surgery he found that skin got short due to inactive condition of underlying muscles. Correct apposition of muscle regained the activity of muscle which results in lengthening of skin ${ }^{(12,13)}$. It also has disadvantage of longer lip. Still there is no technique which give ideal functional result ${ }^{(6)}$.

\section{Materials and Methods}

Prospective study was conducted from October 2018 to October 2019 after ethical approval from institute ethical board. Informed consent was obtained from patients guardians after complete elaboration of study. Purpose of this study was to contrast results of two surgical methods for correction of Unilateral Cleft lip. Study was performed in Bahawal Victoria hospital Bahawalpur. Patients of age 10 to 18 years who were suffering from unilateral cleft lip were selected for the study. Any patients with bilateral cleft lip and operated excluding Millard's and Delaire's method. Non probability consecutive sampling technique was used.

All patients of age 10 weeks to 20 years were selected for study. Patients with unilateral cleft lip were studied. Surgical procedure was performed by qualified or skilled surgeons under general Anesthesia. Total patients were divided in two groups, one group was dealt surgically through Millard's Method while other group was dealth through Delaire Method. Few things were noticed in both surgeries with the help of Steffensen's Criteria. Following things were noticed in both operated individual results which includes, White roll match, Vermillion match, Scar appearance, Cupid bow, lip length, nostril symmetry, alar dome and alar base with respect of Steffensen's Criteria ${ }^{(6,14,15)}$.These surgeries were performed by same surgeon.

Data was collected than arranged over Microsoft Excel 2007.Variables then formed or for further statistical results data was entered in SPSS version 15.0. Variables were assessed by using. Standard Deviation and Mean was calculated.Variables related to Age and gender formed in SPSS version 15.0. Chi Sequare test was used to test the effect modifications. $\mathrm{P}$ value $\leq 0.05$ was considered for level of significance.

\section{Results:}

Out of $100 \%(n=66)$ unilateral cleft lip patients, $50 \%(n=33)$ patients each were operated with Modified Millard's incision and Delaire's functional method respectively. The mean age and weight of the patients,in Millard's group,was $13.85 \pm 1.88$ months and $6.69 \pm 1.23 \mathrm{~kg}$ respectively. There were $54.5 \%(\mathrm{n}=18)$ males and $45.5 \%(\mathrm{n}=15)$ females. The mean age and weight of the patients, in Delaire's group,was $13.96 \pm 1.44$ months and $6.81 \pm 1.33 \mathrm{~kg}$ respectively. There were $66.7 \%(\mathrm{n}=22)$ males and $33.3 \%(\mathrm{n}=11)$ females. No significant difference was found between demographic variables in groups. (Table. 2).

Various parameters were analyzed - white roll match, cupid bow, lip length and alar dome demonstrated favorable measurements in Millard's group and the vermilion match, scar appearance, nostril symmetry and alar base was better in Delaire's methods. All the differences in these parameters were not statistically significant, except lip length $(\mathrm{p}=0.023)$. (Table. 3$)$. 
Table. 1

\section{Grading criteria}

\begin{tabular}{|c|c|c|c|}
\hline Parameters & Good & Average & Poor \\
\hline White roll match & Perfect & Diparity of $<1 \mathrm{~mm}$ & Disparity of $>1 \mathrm{~mm}$ \\
\hline Vermilion match & Perfect & Diparity of $<1 \mathrm{~mm}$ & Disparity of $>1 \mathrm{~mm}$ \\
\hline Scar appearance & No hypertrophy & $\begin{array}{l}\text { Hypertrophy with no } \\
\text { disturbance of cupid bow } \\
\text { or columella }\end{array}$ & $\begin{array}{l}\text { Hypertrophy with } \\
\text { disturbance of cupid bow } \\
\text { or columella }\end{array}$ \\
\hline Cupid bow & Perfect & $\begin{array}{c}\text { Distortion on cleft side } \\
\text { is }<2 \mathrm{~mm} \\
\end{array}$ & $\begin{array}{c}\text { Distortion on cleft side } \\
\text { is }>2 \mathrm{~mm}\end{array}$ \\
\hline Lip length & $\begin{array}{l}\text { Equal length on cleft and } \\
\text { non-cleft side }\end{array}$ & $\begin{array}{c}\text { Shorter of cleft side }>1 \\
\mathrm{~mm}<2 \mathrm{~mm}\end{array}$ & Shorter of cleft side $>2 \mathrm{~mm}$ \\
\hline Nostril symmetry & $\begin{array}{l}\text { Equal height and width to } \\
\text { normal side }\end{array}$ & $\begin{array}{c}>1 \mathrm{~mm}<2 \mathrm{~mm} \text { in either } \\
\text { height or width to normal } \\
\text { side }\end{array}$ & $\begin{array}{l}>2 \mathrm{~mm} \text { in either height or } \\
\text { width to normal side }\end{array}$ \\
\hline Alar dome & $\begin{array}{l}\text { Equal curvature to normal } \\
\text { side }\end{array}$ & -- & $\begin{array}{c}\text { Any depression compared } \\
\text { to normal side }\end{array}$ \\
\hline Alar base & $\begin{array}{c}\text { At the same level of } \\
\text { normal side }\end{array}$ & $\begin{array}{c}\text { Difference of }<1 \mathrm{~mm} \\
\text { compared to normal side }\end{array}$ & $\begin{array}{c}\text { Difference of }>1 \mathrm{~mm} \\
\text { compared to normal side }\end{array}$ \\
\hline
\end{tabular}

Table. 2

\section{Demographic Variables}

\begin{tabular}{|c|c|c|c|}
\hline Variable & $\begin{array}{c}\text { Millard's } \\
(\mathbf{n}=\mathbf{3 3})\end{array}$ & $\begin{array}{c}\text { Delaire's } \\
(\mathbf{n}=\mathbf{3 3})\end{array}$ & Test of Sig. \\
\hline Age & $13.85 \pm 1.88 \mathrm{months}$ & $13.96 \pm 1.44 \mathrm{months}$ & $\chi^{2}=0.992, \mathrm{p}=0.319$ \\
\hline Weight & $6.69 \pm 1.23 \mathrm{~kg}$ & $6.81 \pm 1.33 \mathrm{~kg}$ & $\mathrm{t}=-0.386, \mathrm{p}=0.703$ \\
\hline Gender & $\mathrm{M}=54.5 \%, \mathrm{~F}=45.5 \%$ & $66.7 \%, 33.3 \%$ & $\chi^{2}=1.01, \mathrm{p}=0.314$ \\
\hline
\end{tabular}

Table. 3

Qualitative analysis according to Steffensen's criteria

\begin{tabular}{|c|c|c|c|c|c|}
\hline Characteristics & Group & $\begin{array}{l}\text { Good } \\
\mathrm{n}, \%\end{array}$ & $\begin{array}{c}\text { Average } \\
\mathbf{n}, \%\end{array}$ & $\begin{array}{l}\text { Poor } \\
\text { n, \% }\end{array}$ & P-value \\
\hline \multirow[t]{2}{*}{ White roll match } & Millard's & $16,48.5$ & $12,36.3$ & $5,15.2$ & \multirow[t]{2}{*}{0.964} \\
\hline & Delaire's & $17,51.5$ & $11,33.3$ & $5,15.2$ & \\
\hline \multirow[t]{2}{*}{ Vermilion match } & Millard's & $17,51.5$ & $15,45.5$ & $1,3.0$ & \multirow[t]{2}{*}{0.969} \\
\hline & Delaire's & $18,54.6$ & $14,42.4$ & $1,3.0$ & \\
\hline \multirow[t]{2}{*}{ Scar appearance } & Millard's & $12,36.3$ & $16,48.5$ & $5,15.2$ & \multirow[t]{2}{*}{0.445} \\
\hline & Delaire's & $15,45.5$ & $16,48.5$ & $2,6.0$ & \\
\hline \multirow[t]{2}{*}{ Cupid bow } & Millard's & $14,42.4$ & $16,48.5$ & $3,9.1$ & \multirow[t]{2}{*}{0.188} \\
\hline & Delaire's & $9,27.3$ & $23,69.7$ & $1,3.0$ & \\
\hline \multirow[t]{2}{*}{ Lip length } & Millard's & $21,63.7$ & $11,33.3$ & $1,3.0$ & \multirow[t]{2}{*}{0.023} \\
\hline & Delaire's & $10,30.3$ & $22,66.7$ & $1,3.0$ & \\
\hline \multirow[t]{2}{*}{ Nostril symmetry } & Millard's & $5,15.2$ & $15,45.5$ & $13,39.3$ & \multirow[t]{2}{*}{0.759} \\
\hline & Delaire's & $4,12.1$ & $18,54.6$ & $11,33.3$ & \\
\hline \multirow[t]{2}{*}{ Alar dome } & Millard's & $4,12.1$ & $2,6.1$ & $27,81.8$ & \multirow[t]{2}{*}{0.824} \\
\hline & Delaire's & $5,15.2$ & $3,9.1$ & $25,75.7$ & \\
\hline \multirow[t]{2}{*}{ Alar base } & Millard's & $16,48.5$ & $16,48.5$ & $1,3.0$ & \multirow[t]{2}{*}{0.449} \\
\hline & Delaire's & $21,63.7$ & $11,33.3$ & $1,3.0$ & \\
\hline
\end{tabular}




\section{Discussion}

Cleft lip is considered as one of the more occurring birth defects out of all congenital anomalies. This problem has low incidence among all live births so it is considered as less fatal health problem. But this problem affects cosmetic beauty of individuals. These type of anomalies disturb different normal functioning of patients like sucking, speaking and breathing. Treatment of cleft lip is very difficult.

To improve the quality of surgical results one has to involve different disciplines for its proper management. But many individuals do not participate with different disciplines because of communication gap, low economical status, cultural differences or due to unawareness regarding treatment protocols ${ }^{(16) .}$

The main purpose of the treatment include proper appearance of lip \& nose, proper speech or patent airway or normal chewing process. These type of problems affects patients and their family psychologically as well as behaviorally. To repair one sided cleft lip Campbell et al created appropriate length op upper lip and nose tip in symmetrical position accompanying normal function by treating all facial anomalies ${ }^{(17) .}$

While Tennison explained triangular flap approach to form Cupid's bow. Randall further worked over these techniques to get more precise results. Some unnatural scars appeared due to this techniques accros the Philtral column. In 1955 Millard's brought rotation advancement techniques which depicts more advance results than previous techniques. This technique is most appreciated technique for correcting one sided cleft lip.

Functions of all muscles and their associate relationship with congenital anomalies was completely understood $^{(18)}$. In treatment regiem comparision we found precise therapeutic results by patients of Millard's group than the patients of Delaire's functional group. After getting good therapeutic results still it is questionable that why this is beneficial for unilateral cleft lip ${ }^{(10,19)}$. But nasal height was more precise in patients of Delaire's group than Millard's group. Members of Millard's group were showing better nasal width but their nostril were constrict post operatively. Surgical correctness become difficult as the cartilage and skin becomes mature. Surgery in early stage is easy ${ }^{(20)}$.

This Muscle repair technique gave many precise surgical effects. A pediatric surgeon Victor Veau was considered as Father of Cleft surgeries in $20^{\text {th }}$ Century. Victor Veau wrote a book "Bec de Lievre" which is considered as standardized book for surgeons for repairing clefts of lip. In his book he explained functional and surgical treatment key points in a beautiful way ${ }^{(7)}$.

Conclusion: Overall clinical outcomes like vermilion match, white roll, and cupid bow appearance was similarly effective in both techniques. Lip length outcome was better in modified Millard's incision technique. Similarly nasal symmetry was better in functional Delaire's method. So one Surgical technique found effective.

\section{References}

1. Miachon MD, Leme PL. Surgical treatment of cleft lip. Rev col Bras Cir. 2014;41(3):208-214.

2. Sadove M, van Aalst JA, Culp JA. Cleft palate repair: art and issues. Clin Plast Surg. 2004;31:231-241.

3. Goodacre T, Swan MC. Cleft lip and palate. Pediatr Child Health. 2008;18:64.

4. Derijicke A, Eerens C (1996) Carels: the incidence of oral clefts: a review. Br J Oral Maxillofac Surg. 1996;34:488-494.

5. Theogaraj SD, Joseph LBM, Mani M. Statistical analysis of 750 cleft lip and palate patients. IJPS. 2007;40:1

6. Reddy GS, Webb RM, Reddy RR, Reddy LV, Thomas P, Markus AF. Choice of incision for primary repair of unilateral complete cleft lip: a comparative study of outcomes in 796 patients. Plast and Reconstr Surg. 2008;121(3):932-940.

7. Bill J, Proff P, Bayerlein T, Weingartner J, Fanghanel J, Reuther J. Treatment of patients with cleft lip, alveolus and palateshort outline of history and current interdisciplinary treatment approaches. J CranioMaxillofac Surg. 2006;34(Supplement S2):17-21.

8. Pennisi VR, Shadish WR, Klabunde EH. Orbicularis Oris muscle in the cleft lip repair. Cleft Palate J. 1996;6:141-153.

9. Millard DR Jr. Rotation-advancement principle in cleft lip closure. Cleft Palate J. 1964;12:246-252.

10. Millard DR Jr. Refinements in rotation-advancement cleft lip technique. Plast Reconstr Surg. 1964;33:26-38. 
11. Park CG, Ha B. The importance of accurate repair of the orbicularis muscle in the correction of unilateral cleft lip. Plast Reconstr Surg. 1995;96:780.

12. Markus AF, Delaire J. Functional primary closure of cleft lip. Br J Oral Maxillofac Surg. 1993;31:281291.

13. Horswell BB, Pospisil OA. Nasal symmetry after primary cleft lip repair: comparison between Delaire cheilorhinoplasty and modified rotation-advancement. J Oral Maxillofac Surg. 1995;53:1025-1030.

14. Noordhoff MS. Reconstruction of vermilion in unilateral and bilateral cleft lips. Plast Reconstr Surg. 1984;73(1):52-60.

15. Musgrave RH, Garrett WS. The unilateral cleft lip. Reconstr Plast Surg 1977;43:2016-2047.

16. Li WS, Dai JB, Li YG, Wei SC. Clinical investigation for bilateral cleft lip repair: modified functional bilateral cleft lip cheilorrhaphy. J Oral Maxillofac Surg. 2008;66:21-28.

17. Campbell A, Costello BJ, Ruiz RL. Cleft lip and palate surgery. An update of clinical outcomes for primary repair. Oral Maxillofac Surg Clin N Am. 2010;22:43-58.

18. Mehrotra D, Pradhan R. Cleft lip: our experience in repair. J Maxillofac Oral Surg. 2010;9(1):60-63 .

19. Asensio $\mathrm{O}$. A variation of the rotation advancement operation for repair of wide unilateral cleft lips. Plast Reconstr Surg 1974;53(2):167-173.

20. Salyer KE. Primary correction of unilateral cleft lip nose: a 15 year experience. Plast Reconstr Surg 1986;77:558. 